\title{
PERANCANGAN AWAL PABRIK BIOHIDROGEN DARI LIMBAH CAIR PABRIK KELAPA SAWIT DENGAN FERMENTASI ANAEROBIK PADA KONDISI TERMOFILIK
}

\author{
Bambang Trisakti, Irvan, Hari Tiarasti, Irma Suraya \\ Departemen Teknik Kimia, Fakultas Teknik, Universitas Sumatera Utara \\ Jl. Almamater, Kampus USU Medan 20155, Indonesia \\ b_trisakti@yahoo.com
}

\begin{abstract}
Abstrak
Indonesia memiliki banyak sumber daya alam namun tidak mencukupi lagi untuk memenuhi permintaan energi dari konsumen, khususnya bahan bakar. Oleh karena itu, pemerintah terus menggalakkan mencari energi alternatif terbaru. Salah satunya adalah hidrogen. Hidrogen merupakan produk ramah lingkungan yang tidak menghasilkan emisi gas karbon. Dalam pembentukan hidrogen dapat menggunakan limbah yang kaya akan karbohidrat sebagai bahan baku dan dilakukan proses fermentasi. Akan tetapi, hingga saat ini masih sebatas penelitian saja. Sehingga hal ini mendorong dibuatnya suatu perancangan awal pabrik pembuatan biohidrogen dari limbah cair pabrik kelapa sawit (LCPKS) dengan fermentasi anerobik pada kondisi termofilik dengan tujuan mencukupi kebutuhan konsumen dan turut berperan dalam mengembangkan teknologi bersih. Untuk kapasitas produksi sebesar 495,1694 ton/tahun, total investasi yang dibutuhkan untuk membangun sebuah pabrik biohidrogen di Indonesia adalah $R p$. 507.190.573.523,-- dengan total biaya produksi sebesar Rp. 354.636.600.139,-. Parameter kelayakan dengan kapasitas produksi 495,1694 ton/tahun adalah total penjualan produk sebesar Rp 174.261.989,701,- dan laba bersih sebesar 180.030.185.327,-. Profit Margin (PM) 41,9\%, Break Even Point (BEP) 45,24 \%, Return on Investment (ROI) 35,5 \%, Pay Out Time (POT) 2,82 tahun, Return on Network (RON) 59,16\%, Internal Rate of Return (IRR) 53,52\%.
\end{abstract}

Kata kunci : biohidrogen, fermentasi anaerobik, IRR, LCPKS,termofilik.

\begin{abstract}
Indonesia has a lot of natural resources which is deficient to fulfill the energy demand of consumers, particularly fuel. Therefore, the government keeps on promoting the search for alternative energy. One of these is hydrogen. Hydrogen is an environmental friendly product that does not produce carbon emissions. In the formation of hydrogen we can use carbohydrate-rich waste as a raw material and by using fermentation process. However, it is still limited research only. So this encourage us to design biohydrogen plant from palm oil mill effluent (POME) with the conditions of thermophilic anaerobic fermentation in order to accomplish the needs of consumers and contribute in developing clean technologies. For the production capacity of 495.1694 tons / year, the total investment required to build a factory of biohydrogen in Indonesia is Rp. 507,190,573,523, - with a total production cost of Rp. 354,636,600,139, -. Parameter feasibility of the production capacity of 495.1694 tons / year is the total product sales of $R p$ 174,261,989.701, and net income 180,030,185,327, -. Profit Margin (PM) 41.9\% Break Even Point (BEP) 45.24\%, Return on Investment (ROI) 35.5\%, Pay Out Time (POT) 2.82 years, Return of Network (RON) $59.16 \%$, Internal Rate of Return (IRR) $53.52 \%$.
\end{abstract}

Keywords: anaerobic fermentation, biohydrogen, IRR, POME, thermophilic.

\section{Pendahuluan}

Pada saat ini, dunia menghadapi dua krisis yaitu kekurangan bahan bakar fosil perubahan iklim secara global. Perubahan iklim secara luas diyakini terkait dengan peningkatan pesat dalam kerusakan yang disebabkan oleh bencana alam selama 30 tahun terakhir dan konsekuensi global yang disebabkan oleh konsentrasi gas efek rumah kaca meningkat. Maka, sangat dibutuhkan alternatif lain untuk menggantikan bahan bakar yang bersumber dari fosil [1]. Untuk antisipasi dalam memenuhi pasokan akan kebutuhan energi, energi terbarukan yang ramah lingkungan antara lain : bioetanol, bio-diesel,bio-hidrogen $\left(\mathrm{Bio}-\mathrm{H}_{2}\right)$, bio-butandiol (Bio-BD) [2]. Dari berbagai pilihan, hidrogen dan metana mempunyai peran yang penting dalam energi masa depan karena ramah lingkungan, dapat diperbaharui, sustainable dan energi yang digunakan rendah [1].

Lebih dari 500 milyar $\mathrm{m}^{3}$ dari hidrogen diproduksi tiap tahun untuk digunakan dalam berbagai macam proses. Jumlah ini dapat menghasilkan 6,5 EJ dari energi dan setara dengan konsumsi $1,5 \%$ dari energi dunia. Sembilan puluh sembilan persen (99\%) dari hidrogen dihasilkan dari bahan bakar fosil terutama natural gas, sedangkan sumber dari yang dapat diperbaharui sisanya. Saat ini penggunakan katalitik steam 
reforming dari nafta atau natural gas, gasifikasi batu bara dan elektrolisis air sangat digemari sebagai metode klasik untuk pabrikasi hidrogen. Tetapi, semua metode tersebut menggunakan energi yang tinggi, biaya yang tinggi dan tidak ramah lingkungan. Oleh karena itu, teknik yang sesuai untuk memproduksi energi tersebut adalah dengan biomassa atau limbah yang tersedia[3].

Gas hidrogen $\left(\mathrm{H}_{2}\right)$ mempunyai gravimetrik densitas energi yang paling tertinggi diantara beberapa bahan bakar dan cocok terhadap elektrokimia dan proses pembakaran untuk konversi energi tanpa menghasilkan emisi karbon yang telah memberikan konstribusi pada polusi lingkungan dan perubahan iklim. Sekarang ini, sebagian besar $\mathrm{H}_{2}$ diproduksi dengan cara elektrolisa air atau perubahan dari metan. Teknologi produksi $\mathrm{H}_{2}$ secara bio $\left(\right.$ Bio- $\left.\mathrm{H}_{2}\right)$ memberikan pendekatan yang luas terhadap produksi $\mathrm{H}_{2}$ termasuk biofotolisis langsung, biofotolisis tidak langsung, foto fermentasi dan fermentasi gelap. Fermentasi tanpa menggunakan cahaya ini merupakan salah satu energi bersih masa depan untuk menuju sasaran tanpa limbah dikarenakan dapat dipakainya limbah pertanian dan limbah industri sebagai substrat mikroorganisma [4].

Biomassa dari limbah yang dapat dimanfaatkan untuk biohidrogen ini salah satunya adalah limbah cair kelapa sawit. Pabrik pengolahan kelapa sawit menghasilkan limbah cair dalam jumlah yang besar, yaitu satu ton tandan buah segar (TBS) dapat dikonversi menjadi 0,2 ton Crude Palm Oil (CPO), sementara 0,66 ton akan dikonversi menjadi limbah cair pabrik kelapa sawit (LCPKS) [5]. LCPKS mengandung asam amino, nutrisi inorganik seperti $\mathrm{Na}, \mathrm{K}, \mathrm{Ca}, \mathrm{Mg}$, serat pendek dan campuran dari karbohidrat. Oleh karena itu LCPKS sangat sesuai sebagai substrat untuk produksi hidrogen [6].

Adapun potensi LCPKS atau palm oil mill effluent (POME) untuk menghasilkan biohidrogen dapat dijelaskan pada hasil beberapa penelitian pada gambar 1 .

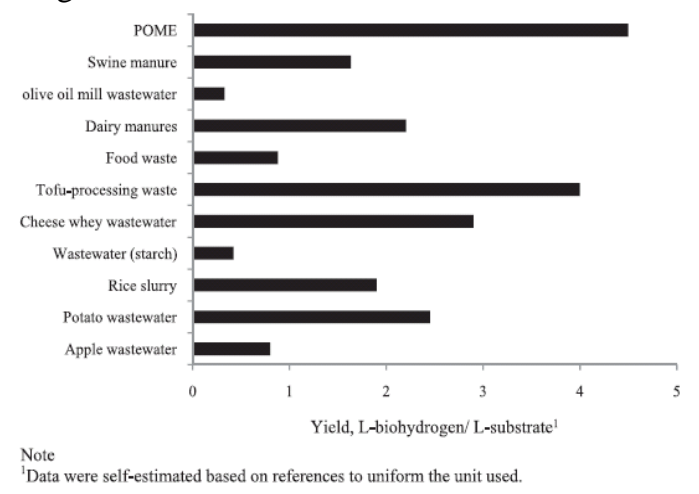

Gambar 1. Yield dari biohidrogen dengan menggunakan umpan yang berbeda [7]
Konsumsi hidrogen dunia terus meningkat pesat, misalnya untuk industri pupuk dan kilang minyak, saat ini permintaannya mencapai 50 juta ton per tahun, dengan laju sekitar 4-10\% per tahun dan diperkirakan akan meningkat terus dengan laju yang lebih cepat. Pada kilang minyak, hidrogen dimanfaatkan untuk menghasilkan bahan bakar transportasi dengan kadar hidrogen sekitar $15 \%$ sehingga diperoleh bahan bakar transportasi (gasoline, jet fuel) yang ramah lingkungan. Hidrogen juga merupakan kandidat bahan bakar transportasi yang paling menjanjikan di masa yang akan datang. Berbagai uji coba kendaraan fuel cell (yang bersumber dari hidrogen) oleh industriindustri otomotif terkemuka dunia sejak lebih dari 50 tahun terakhir mulai menunjukkan titik terang dalam pemanfaatan fuel cell berbasis hidrogen sebagai bahan bakar kendaraan. Jika hasil uji coba ini memberikan hasil yang positif diperkirakan pada akhir dasawarsa ini akan menjadi awal era mobil fuel cell di dunia. Pada saat itulah akan terjadi lonjakan permintaan hidrogen dalam jumlah sangat besar. Sebagai contoh, studi di Amerika menunjukkan bahwa jika era mobil fuel cell dimulai, Amerika sendiri membutuhkan sekitar 40 juta ton hidrogen per tahun untuk menggerakkan sekitar 100 juta mesin-mesin mobil fuel cell [8]. Oleh karena itu, makin menjaminnya potensi biohidrogen di masa depan menyebabkan perlunya perancangan awal pabrik pembuatan biohidrogen dari LCPKS.

\section{Teori}

Produksi hidrogen dari sumber daya terbarukan dengan fermentasi adalah metode yang lebih menjanjikan di antara alternatif proses produksi hidrogen yang lain. Sesuai dengan pembangunan berkelanjutan dan masalah minimisasi limbah, produksi hidrogen biologis, yang dikenal sebagai "teknologi hijau" telah menerima banyak perhatian dalam beberapa tahun terakhir disebabkan kebutuhan energi yang sedikit dan dapat dikombinasikan dengan proses pengolahan limbah cair. Hidrogen tidak berbau, tidak berwarna, tidak berasa, dan tidak beracun ketika digunakan sebagai bahan bakar karena tidak menghasilkan polutan tetapi menghasilkan air sebagai produk tunggal. Dibandingkan dengan bahan bakar fosil, hidrogen menghasilkan energi sebesar $122 \mathrm{~kJ} / \mathrm{g}, 2,75$ kali lebih besar dibandingkan dengan bahan bakar hidrokarbon [9].

Adapun beberapa keuntungan dari penggunaan hidrogen ialah pembakaran hidrogen pada automobile 50\% lebih efisien dari pada bensin [10]. Kemudian hidrogen mempunyai efisiensi konversi sebesar 55-60\% (Nilai pembakaran gas $\mathrm{H}_{2}$ ) dibandingkan dengan gas metana yang hanya 33\% [11]. Hidrogen dapat 
dijual sebagai metal hydride [12] serta transmisi hidrogen melalui perpipaan gas akan lebih efisien daripada transmisi electricity down power line [13]. Selain itu gas $\mathrm{H}_{2}$ mempunyai aplikasi industri yang lebih luas dibandingkan gas metana [14].

Di antara metode produksi hidrogen, metode yang paling menjanjikan dan ramah lingkungan adalah fermentasi gelap dari limbah organik karena menggabungkan proses produksi hidrogen dengan pengolahan limbah [15].

\section{Metodologi Pembuatan Biohidrogen}

Bahan baku yang digunakan pada proses ini adalah limbah cair pabrik kelapa sawit (LCPKS).

Tahap pembentukan biohidrogen ada 3 yaitu pre-treatment, hidrolisis dan asidifikasi [16]. Proses pre-treatment berfungsi untuk menonaktifkan bakteri metanasi sehingga dihasilkan produksi hidrogen yang tinggi. Metode yang digunakan adalah penambahan $1 \mathrm{M} \mathrm{NaOH}$ $10 \%$ ke dalam LCPKS dan dipanaskan pada suhu $80^{\circ} \mathrm{C}$ selama 1 jam [6]. Pada proses hidrolisis terjadi perombakan rantai panjang karbohidrat menjadi bagian yang lebih pendek dan selanjutnya hasil perombakan itu diubah menjadi hidrogen pada proses asidifikasi. Reaksi yang terjadi yaitu :

$$
\begin{aligned}
& \left(\mathrm{C}_{6} \mathrm{H}_{10} \mathrm{O}_{5}\right)_{\mathrm{n}} \underset{\text { mikroba }}{\longrightarrow} \mathrm{H}_{2(\mathrm{~g})}+\mathrm{CO}_{2(\mathrm{~g})}+\mathrm{H}_{2} \mathrm{~S}_{(\mathrm{g})}+ \\
& \mathrm{C}_{2} \mathrm{H}_{4} \mathrm{O}_{2(\mathrm{i})}+\mathrm{C}_{4} \mathrm{H}_{8} \mathrm{O}_{2(\mathrm{l})}[17]
\end{aligned}
$$

Fermentasi yang digunakan yaitu fermentasi anerobik pada kondisi termofilik dengan temperatur $60^{\circ} \mathrm{C}$, pH 5,5 dan HRT 2 hari. Biohidrogen yang dihasilkan yaitu $61 \% \mathrm{H}_{2}, 85$ ppm $\mathrm{H}_{2} \mathrm{~S}$ dan selebihnya adalah $\mathrm{CO}_{2}$. Selain gas yang dihasilkan, akan diperoleh juga beberapa asam terutama asam asetat dan asam butirat pada effluent. Nilai COD yang dihasilkan juga masih tinggi [18]. Oleh karena itu, dapat dilakukan proses anaerobik untuk menghasilkan biogas yang bisa dimanfaatkan untuk energi listrik pembuatan biohidrogen. Adapun skema proses pembuatan biohidrogen dan biogas dari fermentasi LCPKS ditunjukkan pada gambar 2 .

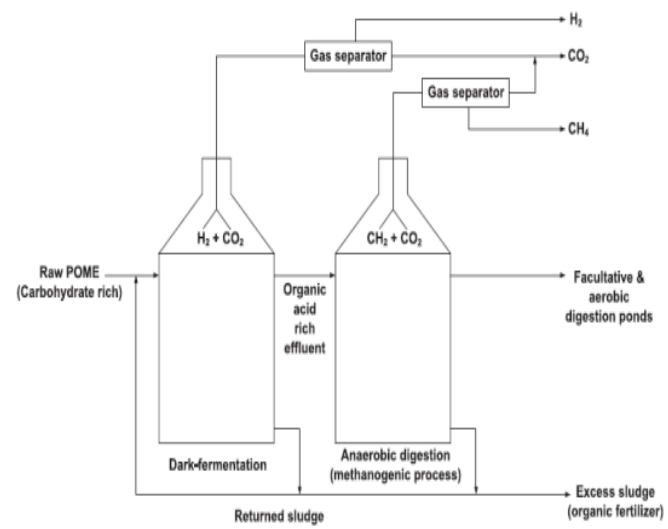

Gambar 2. Sistem integrasi dari fermentasi gelap dengan anaerobik untuk produksi biohidrogen dan biogas [7]

Untuk memurnikan biohidrogen, maka perlu dilakukan pemurnian. Pertama, dilakukan proses biodesulfurisasi. Biodesulfurisasi ini mempunyai beberapa keuntungan diantaranya prosesnya aman karena semua $\mathrm{H}_{2} \mathrm{~S}$ terserap, tidak menggunakan bahan kimia yang mahal, menggunakan tekanan atmosfer dan produk akhirnya adalah elemen sulfur yang dapat dimanfaatkan kembali. Inokulum yang digunakan yaitu Thioalkalivibrio dan Thioalkalimicrobium [19]. Kedua, dilakukan proses penyerapan $\mathrm{CO}_{2}$ menggunakan larutan $\mathrm{K}_{2}{ }_{2} \mathrm{CO}_{3}$ yang dapat diregenerasi. Ketiga, dilakukan proses pemurnian $\mathrm{H}_{2}$ dengan tingkat kemurnian 99\% dengan menggunakan prinsip Pressure Swing Adsorber (PSA).

\section{Hasil}

\section{a. Analisa Proses}

Keunggulan produksi $\mathrm{H}_{2}$ melalui fermentasi anaerobik adalah :

1. Tidak memerlukan energi matahari

2. Berbagai limbah/tanaman energi dapat digunakan

3. Teknologi reaktor yang sederhana [20]

Selain itu, adapun keistimewaan dari perancangan awal pabrik pembuatan biohidrogen ini adalah terbentuknya $\mathrm{H}_{2}$ dengan kemurnian $99 \%$ dan produk lain seperti $\mathrm{CO}_{2}$ dan sulfur yang juga bisa dijual serta pemanfaatan kembali effluent dari fermentasi biohidrogen menjadi biogas yang akan digunakan untuk energi listrik dari pabrik biohidrogen itu sendiri. Flowsheet lengkap dari perancangan awal pabrik ini ditunjukkan pada gambar 4. 


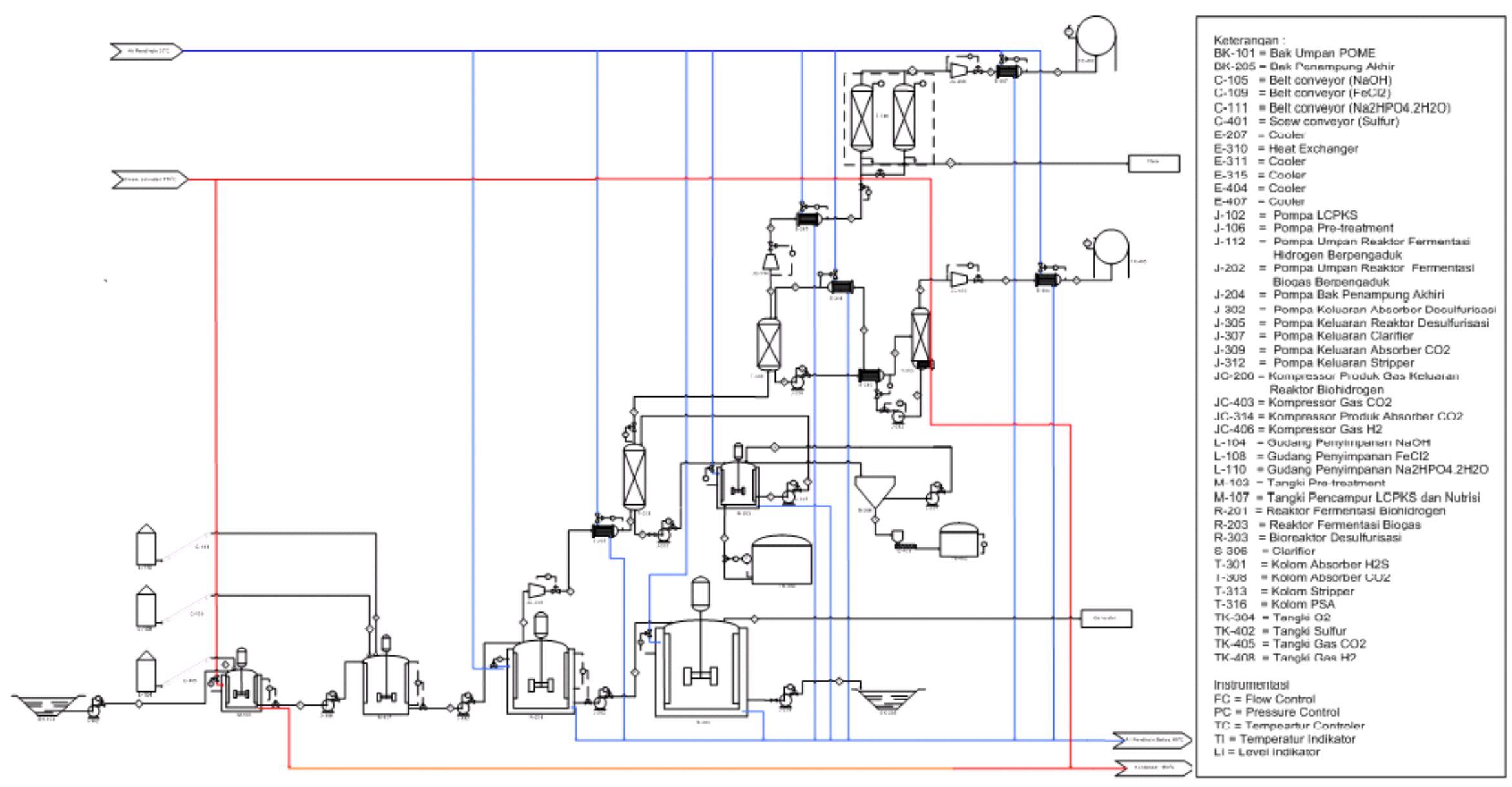

Gambar 3. Flowsheet Pembuatan Biohidrogen dari Fermentasi LCPKS dengan Fermentasi

Anaerobik pada kondisi Termofilik 


\section{b. Analisa Lokasi dan Tata Letak Pabrik}

Pabrik pembuatan biohidrogen ini direncanakan berlokasi di daerah Tebing Tinggi, Provinsi Sumatera Utara dengan alasan bahan baku pabrik merupakan limbah cair proses pengolahan Crude Palm Oil (CPO) yang diperoleh dari Pabrik Minyak Kelapa Sawit (PMKS). Pabrik ini direncanakan terintegrasi dengan PMKS yang ada di sekitar lokasi pabrik. Adapun sumber utama bahan baku direncanakan berasal dari salah satu Pabrik Kelapa Sawit (PKS) di daerah Tebing Tinggi. Kapasitas terpasang di pabrik tersebut adalah 60 ton tandan buah segar/jam sehingga menghasilkan limbah cair sekitar 36 ton/jam. Jumlah limbah cair tersebut telah mencukupi kebutuhan kapasitas pabrik yang akan dibangun.

Kawasan industri Tebing Tinggi ini, tidak terlalu jauh dari sarana pelabuhan Belawan. Selain itu, fasilitas transportasi darat dari industri ke tempat sekitar juga sangat baik dan dekat dengan jalan utama. Air yang dibutuhkan dalam proses diperoleh dari Daerah Aliran Sungai (DAS) Padang yang mengalir di sekitar pabrik untuk proses, sarana utilitas dan kebutuhan domestik.

Sebagai kawasan industri, daerah ini merupakan salah satu tujuan para pencari kerja. Di daerah ini tersedia tenaga kerja terdidik maupun yang tidak terdidik serta tenaga kerja yang terlatih maupun tidak terlatih. Tata Letak Pabrik ditunjukkan pada gambar 4 dengan skala 1: 63.7019 sehingga luas tanah yang dibutuhkan sebesar $13.250 \mathrm{~m}^{2}$. Keterangan gambar disajikan pada Tabel 1 .
Tabel 1. Kode dan Penjelasan untuk Gambar 4

\begin{tabular}{|c|l|}
\hline No. & \multicolumn{1}{|c|}{ Jenis Area } \\
\hline 1 & Pos keamanan \\
\hline 2 & Parkir \\
\hline 3 & Taman \\
\hline 4 & Perumahan Karyawan \\
\hline 5 & Ruang kontrol \\
\hline 6 & Area Proses \\
\hline 7 & Area Utilitas \\
\hline 8 & Perkantoran \\
\hline 9 & Laboratorium \\
\hline 10 & Poliklinik \\
\hline 11 & Kantin \\
\hline 12 & Tempat Ibadah \\
\hline 13 & Gudang Peralatan/Suku Cadang \\
\hline 14 & Bengkel \\
\hline 15 & Perpustakaan \\
\hline 16 & Unit Pemadam Kebakaran \\
\hline 17 & Area Perluasan \\
\hline 18 & Unit Pembangkit Listrik \\
\hline 19 & Jalan \\
\hline
\end{tabular}




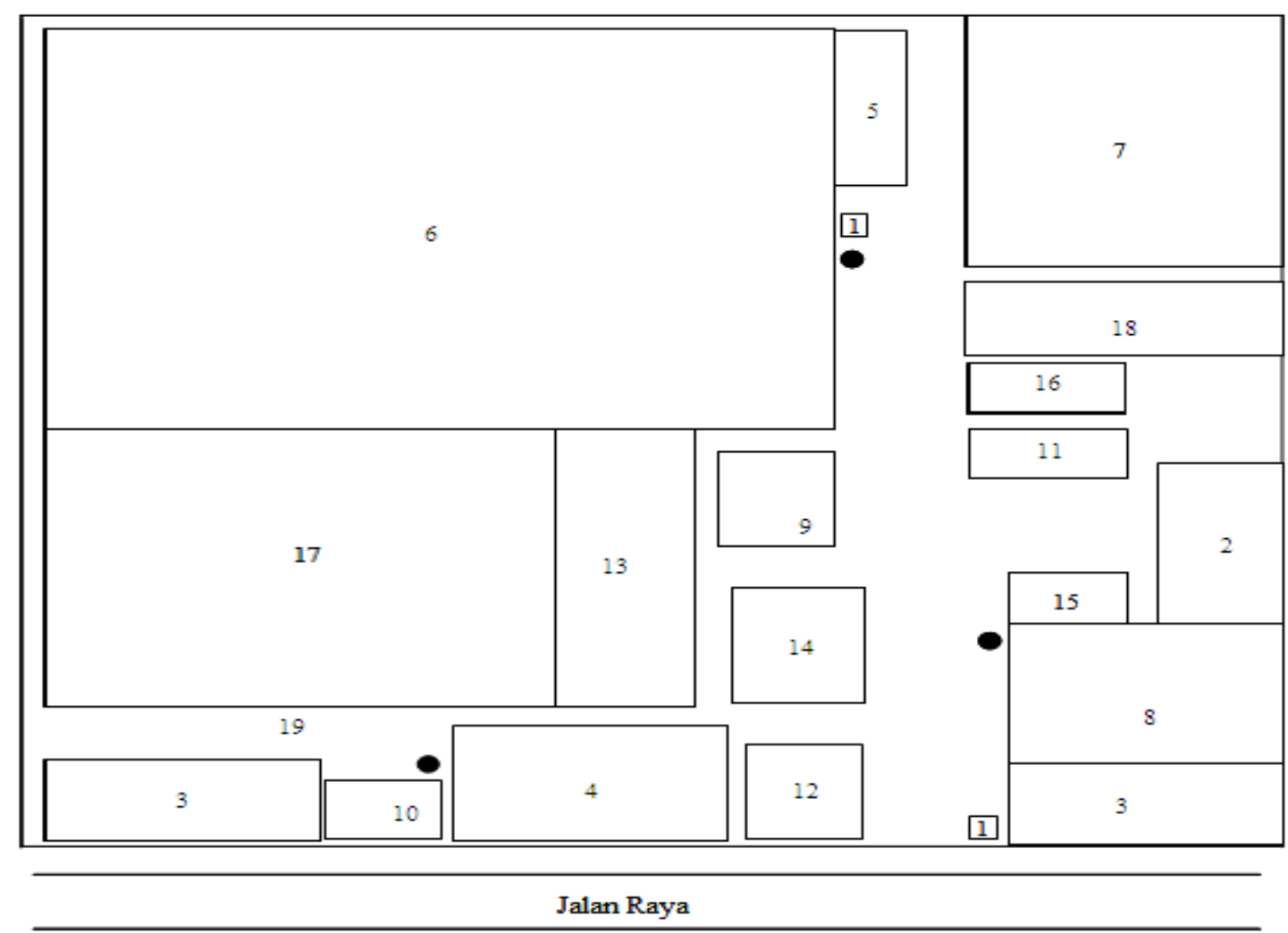

Gambar 4. Tata Letak Pabrik Biohidrogen

\section{c. Analisa Ekonomi}

Untuk kapasitas produksi sebesar 495,1694 ton/tahun, total investasi yang dibutuhkan untuk membangun sebuah pabrik biohidrogen di Indonesia adalah Rp. 507.190.573.523,- dengan total biaya produksi sebesar Rp. 354.636.600.139,-. Parameter kelayakan dengan kapasitas produksi 495,1694 ton/tahun adalah total penjualan produk sebesar Rp 174.261.989,701,- dan laba bersih sebesar 180.030.185.327,-. Profit Margin (PM) 41,9 \%, Break Even Point (BEP) 45,24\%, Return on Investment (ROI) 35,5\%, Pay Out Time (POT) 2,82 tahun, Return on Network (RON) 59,16\%, Internal Rate of Return (IRR) 53,52\%.

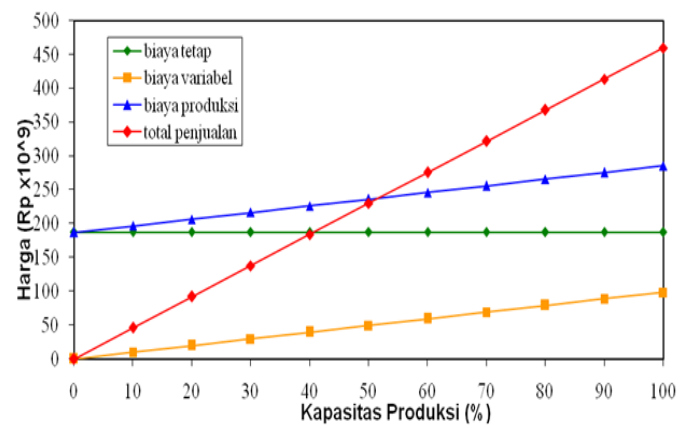

Gambar 5. Grafik Break Even Point Pabrik Pembuatan Biohidrogen

\section{Kesimpulan}

1. Prospek biohidrogen sangat menjanjikan untuk bahan bakar karena melimpahnya bahan baku dan menggunakan teknologi ramah lingkungan.

2. Pabrik ini menghasilkan biohidrogen dengan kemurnian 99\%, karbondioksida, sulfur dan biogas yang berfungsi sebagai bahan bakar pada pabrik ini. Jadi, teknologi yang digunakan sangat terintegerasi.

3. Lokasi pabrik dipilih di Tebing Tinggi, Provinsi Sumatera Utara, disebabkan dekat dengan sumber bahan baku yaitu PKS Rambutan.

4. Untuk kapasitas produksi sebesar 495,1694 ton/tahun, total investasi yang dibutuhkan untuk membangun sebuah pabrik biohidrogen di Indonesia adalah Rp. 507.190.573.523,- dengan total biaya produksi sebesar Rp. 354.636.600.139,--

5. Parameter kelayakan dengan kapasitas produksi 495,1694 ton/tahun adalah total penjualan produk sebesar Rp 174.261.989,701,- dan laba bersih sebesar 180.030.185.327,-. Profit Margin (PM) 41,9 \%, Break Even Point (BEP) 45,24\%, Return on Investment (ROI) 35,5\%, Pay 
Out Time (POT) 2,82 tahun, Return on Network (RON) 59,16\%, Internal Rate of Return (IRR) 53,52\%.

\section{Daftar Pustaka}

[1] Antonopoulou G, Gavala H, Skiadas I, Angelopoulos K, Lyberatos G,. Biofuels generation from sweet sorghum: Fermentative hydrogen production and anaerobic digestion of the remaining biomass. Bioresource Technology, 99(1), 2008, p. 110-119.

[2] Chang J-S,Lee K-S, Lin P-J. Biohydogen production with fixed-bed bioreaktor, Int J Hydrogen Energy. 2002, 27 : p. 167-174.

[3] Nath, Kaushik dan Debabrata Das. Biohydrogen production as a potential energy resource-Present of art. Journal of Scientific \& Industrial Research. Vol. 63, 2004, p.729-738.

[4] Mahyudin dan Koesnandar. Biohydrogen Production : Prospects and Limitations To Practical Application. Akta Kimindo Vol.1 No.2 April 2006. p.73-78.

[5] Chisti Y. Biodiesel from microalgae. Biotechnology Advances 25, 2007, 294-306.

[6] Syafawati Ahmad Kamal, Jamaliah Md Jahim, Nurina Anuar, Osman Hassan, Wan Ramli Wan Daud, Mariatul Fadzillah Mansor and Shah Samiur Rashid. Pre-Treatment Effect of Palm Oil Mill Effluent (POME) during Hydrogen Production by a Local Isolate Clostridium butyricum. Internasional Journal on advanced Science Information Technology. Vol 2 No.4, 2012, ISSN 2088-5534

[7] Kee Lam and Keat Teong Lee. Renewable and sustainable bioenergies production from palm oil mill effluent (POME) : Win-win strategies toward better environmental protection. Biotechnology Advances 29, 2011, p. 124-141.

[8] US-DOE. National Hydrogen Energy Roadmap. National Hydrogen Energy. Roadmap Workshop, Washington DC, 2002.

[9] Chong, Mei Ling and Sabaratnam, Vikineswary and Shirai, Yoshihito dan Hassan, Mohd Ali. Biohydrogen Production by Clostridium butyricum from Palm Oil Mill Effluent. International Journal of Hydrogen Energy 34: 2009, p. 764-771.
[10] Reith JH, Wijffels RH, Barten H, editors. Status and perspectives of biological methane and hydrogen production. Dutch Biological Hydrogen Foundation; 2003, p. 103-23.

[11] Van Groenestijn JW, Hazewinkel JHO, Nienoord M, Bussmann PJT. Energy aspect of Biological Hydrogen Production in High Rate Bioreactors Operated in The Thermophilic Temperature Range. International Journal of Hydrogen Energy 27, 2002, p.1141-1147.

[12] Dong GX, Wu BR, Zhu L, Du J. Microstructure and electrochemical properties of low-temperature hydrogen storage alloy used in $\mathrm{Ni} / \mathrm{MH}$ batteries. Transactions of Nonferrous Metals Society of China, 2007.

[13] Kloeppel J, Rogerson S. The Hydrogen Economy. Electronics World \& Wireless World 97(1666):1991.p.668671.

[14] Li C and Fang HHP. Fermentative Hydrogen Production from Wastewater and Solid Wastes by Mixed Cultures. Critical Reviews in Enviromental Science and Technology 37:2007.p. 139.

[15] Benemann J. Hydrogen Biotechnology: Progress and Prospect. Nature Biotechnology 14:p.1996. 1101-1103.

[16] Kongjan, Prawit. Biohydrogen Process from Sugar rich substrates using the dark fermentation process. Department of Environmental Engineering. Phd Thesis, 2010.

[17] Dawei,Liu. Biohydrogen Production by Dark Fermentation from Organic Wastes and Residues. Thesis Department of Enviromental Engineering. Technical University of Denmark, 2008.

[18] Sompong O-Thong, Poonsuk Prasertsan, Nugul Intrasungkha, Sridu Dhamwichukorn and Nils-Kare Birkeland. Improvement of Biohydrogen production and treatment efficiency on palm oil mill effluent with nutrient supplementation at thermophilic condition using anaerobic sequencing batch reactor. Enzyme and Microbial Technology 41, 2007, P. 583-590.

[19] Van den Bosch, P. L. F, Van Beusekom, O. C, Buisman, C. J. N.; Janssen, A. J. H. Sulfide oxidation at haloalkaline conditions in a fed-batch 
bioreactor. Biotechnology and Bioengineering 97, 2007, P.1053 1063.

[20] Hallenbeck PC, Ghosh D. Advances in fermentative biohydrogen production: the way forward?. Trends Biotechnol, 2009. 